
\title{
$\begin{array}{ll}\text { Research Square } & \begin{array}{l}\text { Preprints are preliminary reports that have not undergone peer review. } \\ \text { They should not be considered conclusive, used to inform clinical practice, } \\ \text { or referenced by the media as validated information. }\end{array}\end{array}$
}

\section{Sorghum Agronomic Performance and Soil Chemical and Microbiological Properties as Influenced by Burkina Faso Phosphate Rock-Enriched Composts}

\author{
Adama Sagnon \\ Japan International Research Center for Agricultural Sciences \\ Shinya Iwasaki \\ Japan International Research Center for Agricultural Sciences \\ Ezechiel Bionimian Tibiri \\ Japan International Research Center for Agricultural Sciences \\ Nongma Armel Zongo \\ Japan International Research Center for Agricultural Sciences \\ Emmanuel Compaore \\ Japan International Research Center for Agricultural Sciences \\ Isidore Juste O. Bonkoungou \\ Japan International Research Center for Agricultural Sciences \\ Satoshi Nakamura \\ Japan International Research Center for Agricultural Sciences \\ Mamadou Traore \\ Japan International Research Center for Agricultural Sciences \\ Nicolas Barro \\ Japan International Research Center for Agricultural Sciences \\ Fidele Tiendrebeogo \\ Japan International Research Center for Agricultural Sciences \\ Papa Saliou Sarr ( $\nabla$ saliou@affrc.go.jp ) \\ Japan International Research Center for Agricultural Sciences https://orcid.org/0000-0002-4478-4463
}

\section{Research Article}

Keywords: BPR-enriched compost, phosphate-solubilizing microbes, soil fertility, Burkina Faso, sorghum yield

Posted Date: January 14th, 2022

DOI: https://doi.org/10.21203/rs.3.rs-1227321/v1

License: (c) (i) This work is licensed under a Creative Commons Attribution 4.0 International License. Read Full License 


\section{Abstract}

Purpose The low availability of phosphorus (P) severely limits crop production in sub-Saharan Africa. We evaluated phosphate rock-enriched composts on soil properties and sorghum growth for use as environment-friendly fertilizers.

Methods Treatments were sorghum straw, compost (Comp), Phosphate Rock (BPR), BPR-enriched compost (P-Comp), BPR-soil-enriched compost (P-Comp-Soil), nitrogen-phosphorus-potassium (NPK, 60-90-30), and control without phosphorus and organic material (CT). Sorgum straw and composts were applied at 1.34 tons ha ${ }^{-1}$. The amounts of nitrogen, phosphorus, and potassium in treatments, except in CT, were adjusted to 60 , $90,30 \mathrm{~kg} \mathrm{ha}^{-1}$, with urea, BPR, and $\mathrm{KCl}$, respectively. Sorghum vr. Kapelga was cultivated and soil samples were collected on days 52 , 93 , and 115 (harvest) for analysis.

Results NPK and P-Comp-Soil provided the best sorghum yields. Soil available P was less in these treatments. P-Comp-Soil-amended soils recorded higher populations of bacteria (16S rRNA), acid phosphatase (aphA), phosphonatase (phnX), glucose dehydrogenase ( $g c d)$ and its cofactor pyrroloquinoline quinone ( $p q q E)$ genes. Phosphate-specific transporter ( $p s t S)$ and arbuscular mycorrhizal fungi $(A M F)$ abundances were generally higher in P-Comp-Soil soils, especially at the early growth stage. This active microbial activity in the P-Comp-Soil added to its initially higher available P justified a better nutrient uptake and yields comparable to NPK. Multivariate analysis also revealed the contribution of nitrogen, carbon, and exchangeable cations in sorghum growth.

Conclusion This study demonstrated that direct phosphate rock application is not effective in sub-Saharan African upland cultivation. Alternative to chemical fertilizers, soils may be amended with phosphate rock-enriched composts, a niche of beneficial microbes improving soil health.

\section{Introduction}

Sub-Saharan Africa is experiencing strong demographic growth, and its population is expected to increase from 1.026 billion in 2017 to 3.078 billion in 2100 (Vollset et al. 2020). This significant population growth undoubtedly requires increasing agricultural production to achieve food security. However, there are several factors constraining sustainable crop production in the region, including the scarcity of soils in major nutrients, especially phosphorus (Lompo et al. 2018). Although use of chemical fertilizers is widely accepted to be necessary to improve soil nutritional quality and agricultural yields, the low level of financial income of the farming population in sub-Saharan Africa is a hindrance to their use (Gemenet et al. 2016). In addition, the excessive use of inorganic fertilizers in some parts of the world is more and more questioned in recent years, due to the negative effect on soil biological properties, severe environmental disturbances and lower agricultural yields in the long run (Rahman and Zhang 2018), and their great contribution to the release of greenhouse gases such as the potent nitrous oxide ( $\mathrm{N}_{2} \mathrm{O}$ ), playing a significant part in global warming (Butterbach-Bahl et al. 2011).

Therefore, the use of environment-friendly fertilizers that can restore the agronomic properties of croplands without constraining sustainable agriculture is a necessity. In this perspective, the easy-to-access resources such as agricultural residues, livestock by-products, and locally sourced phosphate rocks have been long studied as alternative solutions to improve soil properties and enhance plant growth and productivity (Ouédraogo et al. 2001). They improve the soil nutrient budget while shaping soil microbial populations (Shang et al. 2020). Salem et al. (2012) pointed out the effect of composts in improving the biological and physicochemical soil properties and their protective status of plants from pathogens. However, most often, the amount of nutrients available in composts are insufficient to cover the nutritional needs of plants. Phosphate rock (PR), an essential material existing in large deposits in several African countries, including Burkina Faso, is included in soil fertilization strategies via a direct application or is added to composts during the composting process to improve the compost phosphorus content.

Nakamura et al. (2013) found that sub-Saharan African PRs effectively achieve high performance in lowland rice, following direct application, regardless of the PR reactivity and the location investigated. However, under water-limited conditions such as upland cultivation of rice or other crops, the effects of the initial PR direct application may be depressed, although it may enhance the total P of soil and have a residual effect in subsequent cultivations (Nakamura et al. 2016; Nakamura et al. 2020). Since smallholder farmers are interested in producing high yields in first year of cultivation and are not interested in waiting several years to benefit from the residual effects of direct PR application, it is essential to improve the agronomic effectiveness of PR using different technologies. Among these, Biswas and Narayanasamy (2006) suggested using PR as a phosphate source supplement to obtain a compost rich in plant-available phosphorus. Sarr et al. (2020) showed that co-composting sorghum straw residues with Burkina rock phosphate and rhizosphere soil (a source of beneficial microorganisms) significantly increases the available phosphate pool. These authors elucidated the mechanisms of PR solubilization during composting and identified phosphatesolubilizing fungi and microbes harboring the alkaline phosphatase gene as the leading players. Phosphate-solubilizing microorganisms are essential actors in the phosphate availability from organic and inorganic compounds in the soil (Souchie et al. 2006; Anand et al. 2016). They include bacteria, actinomycetes, fungi, and some algae (Ingle and Padole 2017), which use various mechanisms to make phosphate available to plants. Acidification of the medium through organic acid release and the production of acid phosphatases respectively to solubilize inorganic phosphates and mineralize organic phosphates was described as the primary process used by soil microorganisms (Anand et al. 2016).

Page $2 / 17$ 
Microbial genes associated with phosphate solubilization/mineralization encode phosphoesterases, phytases, phosphonatases, phosphatases, phosphate transporters, regulators (Liu et al. 2018), siderophores (Ghosh et al. 2015), and exopolysaccharides (Yi et al. 2008). Therefore, the diversity and abundance of these genes are essential for phosphate solubilization, as reported by Sarr et al. (2020).

In the present study, we evaluated the agronomic performance of composts produced without and with the supplement of Burkina Faso Phosphate rock (BPR) and BPR plus sorghum rhizosphere soil compared with the direct application of PR and other organo-mineral materials such as sorghum straw and chemical fertilizers. Their effect on sorghum yields and soil biological and physicochemical properties were investigated. The study of soil biological properties included quantifying at different cultivation periods, the abundance of the bacterial phosphate-solubilizing glucose dehydrogenase ( $g c d$ ) gene (Suleman et al. 2018), and pyrroloquinoline quinone ( $p q q)$ gene that encodes the cofactor pyrroloquinoline quinone (Sarr et al. 2020). In addition to these microbial genes, arbuscular mycorrhizal fungi (AMF), alkaline phosphatase $(p h o D)$, phosphonatase $(p h n X)$ and acid phosphatase $(a p h A)$ genes responsible for the mineralization of organic phosphate (Liu et al. 2018) were quantified.

\section{Materials And Methods}

\section{Study site}

The experiment was carried out at the Center of Agricultural Research and Training of Saria $\left(12^{\circ} 16^{\prime} \mathrm{N}, 2^{\circ} 09^{\prime} \mathrm{W}, 300 \mathrm{~m}\right.$ altitude) located in the center-west region of Burkina Faso in West Africa. In Burkina Faso, Bationo and Mukwunye (1991) reported on nutrient depletion (especially nitrogen and phosphorous) and water and wind erosion, as the main factors in soil degradation and limitation of crop production. The experiment was conducted from July to November 2019, while the rainy season spread from the wettest months July, August, and September. The rainfall for the 2019-2020 cropping season was $911.9 \mathrm{~mm}$ of water in 70 rain days (CREAF/Saria meteorological data, 2019). The soil type in Saria is a Lixisol (WRB 2006) characterized by a low soil fertility, low water holding capacity, and a soil surface crust causing low water infiltration (Zougmoré 2003). Detailed soil information is available in Ikazaki et al. (2018).

\section{Experimental design and sorghum cultivation}

The experimental design consisted of a completely randomized Fisher block with seven treatments and five replicates. The seven treatments consisted of the three types of compost (Compost, P-Compost, and P-Compost-Soil) implemented by Sarr et al. (2020), a negative control with N (60 kg N ha $\left.{ }^{-1}\right)$ and $\mathrm{K}\left(30 \mathrm{~kg} \mathrm{~K}_{2} \mathrm{O}\right.$ ha $^{-1}$ ) application but without P (NK or CT), sorghum straw (SS), Burkina phosphate Rock (BPR), and NPK as an absolute positive control. In brief, sorghum straw residues were supplemented with BPR during composting to make the P-compost (P-Comp). Pcompost-soil (P-Comp-Soil) was made by adding BPR and sorghum rhizosphere soil to the sorghum straw residues during the fabrication process. Sarr et al. (2020) reported that the P-Comp-Soil contained 13\% higher labile-P than the P-Comp. In the present study, the application rate of the organic materials (SS, Comp, P-Comp, P-Comp-Soil) was $1.34 \mathrm{t} \mathrm{ha}^{-1}$. The NPK treatment corresponded to 60,90 , and $30 \mathrm{~kg}^{-1} \mathrm{of}^{-1}$ nitrogen, phosphorus, and potassium, provided by urea, Triple Super Phosphate (TSP), and $\mathrm{KCl}$, respectively. We designed the field trial to supply the same amount of total $\mathrm{P}$, total $\mathrm{N}$, and $\mathrm{K}$ in all the treatments, except the negative control without $\mathrm{P}$ application. When the amount of $\mathrm{N}$, $\mathrm{P}$, or $\mathrm{K}$ provided by the organic material was inferior to rates in the NPK treatment, we added urea or BPR or KCl to adjust to the exact proportions of the NPK treatment. The only difference between the BPR and NPK treatments was the source of P, which was BPR and TSP, respectively. The singularity of this experiment was that the different treatments, except the negative control, supplied the same amount of total P, but the amount of available phosphorus differed from treatment to treatment. In this situation, any difference in yield would undoubtedly be attributed to the difference in available phosphorus in treatments. The rate of available P was higher in the chemical fertilizer NPK and P-Comp-Soil than in the other treatments in which total P was adjusted using BPR that contains $12.05 \%$ phosphorus corresponding to $36.87 \% \mathrm{PO}_{4}(\mathrm{Nakamura}$ et al. 2015).

After plowing, treatments were spread on their corresponding plots (4 m x $6 \mathrm{~m}$ ), which were $1.5 \mathrm{~m}$ apart inside blocks and in-between blocks, and sorghum (Kapelga variety) was sown at $80 \mathrm{~cm}$ x $40 \mathrm{~cm}$ spacing on 16 July 2019, followed by a reseeding of non-germinated hills on 26 July 2019. Seedlings were thinned to two individual plants per hill, the weeds regularly removed, and insect attacks were monitored and controlled during the cultivation period.

\section{Soil sampling and harvest of sorghum plants}

We collected rhizosphere soil samples for chemical and microbiological analysis on the $52^{\text {nd }}, 93^{\text {rd }}$, and the $115^{\text {th }}$ day after sowing. Three sorghum plants randomly selected from the plot edges were destructively pulled out and carefully shaken to remove the loose soil not tightly attached to the roots. The soil well adhering to the roots (rhizosphere soil) was carefully recovered on paper by hand while wearing sterile gloves, which were changed when moving between plots. A soil aliquot per sample was directly put in $50 \mathrm{ml}$ falcon tubes and stored in an icebox until transportation to the laboratory, where it is kept at $-20^{\circ} \mathrm{C}$ until DNA extraction and molecular analysis. The remaining soil part was air-dried and later used for physicochemical analysis. Sorghum was harvested on the $115^{\text {th }}$ day after sowing in a yield area containing 21 plant hills. The 
sorghum biomass was air-dried for two weeks under the sun, and a sub-sample was oven-dried at $75^{\circ} \mathrm{C}$ for $48 \mathrm{~h}$ to calculate the moisture content and determine the dry biomass production per plot. At harvest, the weight of the air-dried grains per plot was recorded after dehulling the ears. A sub-sample of grains was oven-dried in the same way as the sorghum biomass to obtain the oven-dry grain production per plot. Finally, all dry yields were converted to $\mathrm{tha}^{-1}$. The number of total ears per yield area and that of ears with no grain were also counted at harvest

\section{Chemical analysis of soil samples}

The dried rhizosphere soil samples were sieved with a 2-mm mesh and used for physicochemical analysis at the Soil-Plant Laboratory of the Japan International Research Center for Agricultural Sciences (JIRCAS), Tsukuba, Japan. The pH was measured at a 1:2 soil-to-distilled water slurry by a compact pH meter LAQUAtwin-pH-22 (Horiba Scientific, Japan). The dry combustion method was used to determine total carbon and total nitrogen using an NC analyzer (Sumigraph NC-220; Sumika Chemical Analysis Service, Ltd., Japan). Exchangeable cations were extracted with a $1 \mathrm{M}$ ammonium acetate solution. Cation concentrations were determined by the Inductively Coupled Plasma Optical-Emission Spectroscopy (ICP-OES) using the ICPE-9000 (Shimadzu Inc. Tokyo, Japan). Soil available phosphorus was extracted using a Bray-2 extracting solution (Bray and Kurtz 1945), and the concentration of $\mathrm{P}$ in the filtrate were determined using the colorimetric method described by Murphy and Riley (1962) with a UV-1800 spectrophotometer (Shimadzu, Japan).

\section{Extraction of soil DNA}

Soil previously kept at $-20^{\circ} \mathrm{C}$ was left at room temperature for approximately one hour to melt the attached ice. Following that, $0.25 \mathrm{~g}$ of soil sample was used for total DNA extraction using the DNeasy PowerSoil Pro Kit (QIAGEN, Germany) according to the manufacturer's instructions with a slight modification. In step five (5), we used an automatic homogeniser (TissueLyser II, QIAGEN, Germany) instead of a rotary shaker. DNA concentration was assessed using Qubit HS before and used for further molecular analysis. After placing about $0.5 \mathrm{~g}$ of soil in a hot plate at $100^{\circ} \mathrm{C}$ for three (3) hours, the soil moisture percentage was determined by the formula:

$\%$ moisture $=\frac{\text { fresh soil weight }- \text { dry soil weight }}{\text { fresh soil weight }} \times 100$

\section{Determination of the abundance of soil bacteria, fungi, arbuscular mycorrhizal fungi, and several microbial genes involved in P solubilization or mineralization by qPCR}

The extracted sorghum rhizosphere soil DNA was used to quantify the abundance of total bacteria (16S rRNA), fungi (ITS), arbuscular mycorrhizal fungi (AMF), and several genes related to phosphate solubilization, following qPCR methods, plasmid standards, and primers described by Sarr et al. (2020). P-solubilizing genes included glucose dehydrogenase ( $g c d$ ) (Chen et al., 2015) and the pyrroloquinoline quinone (pqqE) (Choi et al. 2008), acting as a cofactor of gcd to synthesize organic acids responsible for the solubilization of inorganic phosphate. The other microbial genes are those involved in the mineralization of organic phosphates, such as acid phosphatase (aphA), alkaline phosphatase $(p h o D)$, phosphonatase (phnX), enterobactin-mediating siderophore (entA), and phosphate specific transporter (pstS) (Bergkemper et al. 2016). However, in this study, AMF was amplified using AML1 (5'-ATCAACTTTCGATGGTAGGATAGA-3') and AML2 (5'- GAACCCAAACACTTTGGTTTCC$3^{\prime}$ ) primers of Lee et al. (2008), with the annealing temperature set to $58{ }^{\circ} \mathrm{C}$ for both PCR and qPCR. The amplification efficiencies/ $\mathrm{r}^{2} \mathrm{values}$ were 81.4\%-93.9\%/0.995-0.999, 79.5\%-83.3\%/0.999-1.000, 76.7\%-87.0\%/0.998-0.999, 83.2\%-84.5\%/0.997-0.999, 95.2\%-102.2\%/0.997-0.999, 83.7\%-93.6\%/0.996-0.999, 57.2\%-60.0\%/0.999, 75.0\%-94.5\%/0.996-0.999, 91.7\%-102.1\%/0.997-0.999, 73.5\%-76.2\%/0.996-0.999 for bacteria (16S rRNA), fungi (ITS), AMF, gcd, pqqE, aphA, phoD, phnX, entA, and pstS, respectively.

\section{Statistical analysis}

The soil chemical and microbiological data obtained from three sampling periods $\left(52^{\text {nd }}, 93^{\text {rd }}\right.$, and the $115^{\text {th }}$ day after sowing) were subjected to a two-way analysis of variance (ANOVA) to evaluate the impact of treatments and sample collection periods on these parameters. These statistical analyses were all performed using CropStat ver. 7.2 software (IRRI, Philippines). When no significant interaction was found between treatments and sampling days, the average value of the given treatment at the three sampling dates was considered ( $\mathrm{n}=9$ ). In case of a significant interaction between the treatment and the sampling day $(p<0.05)$, the data obtained from each sampling day were analyzed separately following one-way ANOVA. A significant interaction indicates that the treatment would behave differently for a given variable from one sampling period to another. When a significant effect is observed, the differences between treatments were tested using Fisher's LSD (Least Significant Difference). When the number of treatments was superior or equal to six, we compared the means using the DMRT (Duncan Multiple Range Test).

Principal Component Analysis (PCA) was performed using the "stats" package of R version 4.0.0 (R Core Team, 2020) to study the general relationships between sorghum yield components and soil chemical and microbiological parameters of the three sampling periods. Before running PCA, the data of the five replicates of each variable were averaged, and the resulting data set was standardized. Calculated principal components were visualized in the PC1/PC2, and PC1/PC3 (components with the highest scores) planes using the R packages ggplot2 
(Wickham 2016) and ggbiplot (Vu 2011). In addition, Spearman's rank correlations (rs) relating yield components and soil properties were obtained using PAST v.2.17 (Hammer et al. 2001). Yield components included sorghum dry grain yields (DGY), dry biomass yields (DBY). Soil chemical characteristics included total carbon (TC), total nitrogen (TN) soil acidity $(\mathrm{pH}), \mathrm{C} / \mathrm{N}$, available Bray2-P, the sum of exchangeable cations $(\mathrm{Mg}, \mathrm{Ca}, \mathrm{Na}, \mathrm{K})$; soil microbiological properties included bacteria (16S rRNA), fungi (ITS), and several other microbial genes ( $g c d$, aphA, phoD, entA, pstS, AMF, phnX, and $p q q E)$.

\section{Results}

\section{Sorghum yields}

Table 1 shows the total dry biomass and grain yields of sorghum. Total biomass and grain yields obtained in the NPK and P-Comp-Soil treatments were not significantly different. They gave significantly higher yields than the other treatments, except that there was no significant difference between P-Comp-soil and the Control for biomass yields and between P-Comp-Soil, P-Comp, and Control for grain yields. In general, Sorghum Straw, Comp, P-Comp, and BPR treatments influenced less the sorghum yields. The percentage of good ears (ears well-filled with grains) were significantly higher in the NPK, P-Comp-Soil, P-Comp, and Comp treatments, with slightly higher values in NPK and P-Comp-Soil. The NPK treatment gave $4.43 \mathrm{t} \mathrm{ha}^{-1}$ of total dry biomass, $0.86 \mathrm{t} \mathrm{ha}^{-1}$ of dry grain, while $72.51 \%$ of ears were filled with grains. For the P-Comp-Soil treatment, these values were $3.87 \mathrm{tha}^{-1}, 0.82 \mathrm{t} \mathrm{ha}^{-1}$, and $72.23 \%$, respectively.

\section{Chemical properties of the rhizosphere soil}

The two-way ANOVA applied to the sampling days and treatments showed no significant interaction between these two variables for soil TN, TC, and the sum of exchangeable cations (data not shown). Therefore, the mean values of these three parameters across the three sampling days were considered and are shown in Table 2. Significant differences among treatments were observed in TN and the sum of exchangeable cations. Compared to the Control, Sorghum Straw, and BPR treatments, the soil contained a significantly higher total nitrogen when fertilized with the PComp-Soil, P-Comp, and Comp treatments. However, the nitrogen content in the soil amended with Comp and P-Comp was similar to the NPK treatment. Also, the soil fertilized with P-Comp-Soil contained significantly higher exchangeable cations (1.08 $\mathrm{cmolc} \mathrm{kg}^{-1} \mathrm{dry}$ soil), while the Control and BPR treatments led to the lowest contents with 0.88 soil and 0.87 cmolc kg-1 dry soil, respectively. Table 2 also shows that TN and TC were significantly higher at the early sorghum growth stage $\left(52^{\text {nd }}\right.$ day) and decreased with the cultivation's progress.

A significant interaction existed between the sampling days and the treatments for the $\mathrm{pH}, \mathrm{C} / \mathrm{N}$, and available $\mathrm{P}$ (data not shown). Thus, these parameters were analyzed separately for each sampling day following one-way ANOVA (Table 3). For the pH, significant differences were found between treatments at the $52^{\text {nd }}$ and $93^{\text {rd }}$ days and not at harvest $\left(115^{\text {th }}\right.$ day). Although the soil was, in general, slightly acidic, the acidity was significantly less under P-Comp-Soil, P-Comp, Comp, and Sorghum Straw treatments compared to Control and NPK on the 52 ${ }^{\text {nd }}$ day. At this period, the $\mathrm{pH}$ of the BPR treatment $(\mathrm{pH}=5.43)$ was significantly lower than that of P-Comp-Soil $(\mathrm{pH}=5.60)$ but was the same as that of $\mathrm{P}$ Comp, Comp, and Sorghum Straw. In contrast, the soil amended with the BPR treatment was significantly less acidic ( $\mathrm{pH}=5.90)$ than the remaining six treatments on the $93^{\text {rd }}$ day. At this second soil sampling day, the $\mathrm{pH}$ of the soil fertilized with NPK was significantly lower than that of Sorghum Straw and BPR treatments. The difference among treatments for the $\mathrm{C} / \mathrm{N}$ ratio was only significant on the $93^{\text {rd }}$ day, where $\mathrm{C} / \mathrm{N}$ (9.52) was significantly higher in the Sorghum Straw treatment than all remaining six treatments.

The soil available P (Bray2-P) content followed contrasting patterns on the three sampling periods (Table 3 ). On the $52^{\text {nd }}$ day, it was significantly higher in NPK (32.81 mg kg-1 dry soil) and Sorghum Straw (28.49 $\mathrm{mg} \mathrm{kg}^{-1}$ dry soil) than the other treatments. However, it was not significantly different between the Sorghum Straw and the BPR $\left(26.98 \mathrm{mg} \mathrm{kg}^{-1}\right.$ dry soil) treatment. The Control and the P-Comp treatments recovered fewer amounts of available $\mathrm{P}$ at this period with 9.39 and $12.06 \mathrm{mg} \mathrm{kg}^{-1}$ dry soil, respectively. In contrast, the pattern changed on the $93^{\text {rd }}$ day when Comp, Sorghum Straw, and BPR-treated soil contained significantly higher P with 34.20, 31.89, and $30.32 \mathrm{mg} \mathrm{kg}^{-1}$ dry soil. Sorghum Straw and BPR-treated soil showed similar levels of available P to the NPK treatment with $26.27 \mathrm{mg} \mathrm{kg}^{-1}$ dry soil, while the Control still contained significantly less available P. On the $115^{\text {th }}$ day, the soils treated with Sorghum Straw, Comp, and BPR showed significantly higher P levels corresponding to $35.50,34.03$, and $30.23 \mathrm{mg} \mathrm{kg}^{-1}$ dry soil, almost like the $93^{\text {rd }}$ day. There was no significant difference in available $\mathrm{P}$ between BPR and NPK and NPK, P-Comp-Soil, and P-Comp. We observed an increasing trend in soil P throughout the cultivation period in the Sorghum Straw, Comp, P-Comp, BPR, and a decrease in NPK and P-Comp-Soil treatments, although we did not perform statistical analysis.

\section{Abundance of microbial genes in the rhizosphere soil}

The two-way ANOVA showed significant interactions (data not shown) between sampling days and treatments for the abundance of the soil microbial genes gcd, AMF, and pstS. Therefore, we described these genes on each sampling day following one-way ANOVA, and the results are reported in Table 4. A significant difference among treatments for the gcd gene was observed only on the $52^{\text {nd }}$ day. At this period, the soil 
amended with P-Comp-Soil contained a significantly higher abundance of the gcd gene than the other treatments. The soil of the remaining treatments hosted a similar abundance of gcd except that NPK had a significantly lower abundance of the gene than the control.

On the $52^{\text {nd }}$ day, the soil that received P-Comp contained higher copy numbers of AMF than the group formed by the Control, Sorghum Straw, BPR, and NPK treatments, which showed the least AMF abundance. However, there was no significant difference in soil AMF among P-Comp, PComp-Soil, and Comp. In contrast, Sorghum Straw-amended soil recovered significantly higher copy numbers of AMF on the $115^{\text {th }}$ day (harvest) than all other treatments. It was followed by Comp and P-Comp, while AMF was significantly less abundant under the Control, P-Comp-Soil, BPR, and NPK treatments. We also noticed an increase (about 3-fold) in AMF abundance in the soil at harvest compared to the $52^{\text {nd }}$ day.

The pstS gene was also significantly different among treatments on the $52^{\text {nd }}$ and $115^{\text {th }}$ days, similarly to AMF. It was significantly higher in soils treated with P-Comp-Soil and BPR on the $52^{\text {nd }}$ day than the other five treatments that did not show differences. At harvest, the soil amendment with P-Comp led to a significantly higher abundance of the pstSgene than the remaining six treatments that showed no significant difference.

The two-way ANOVA was not significant between sampling days and treatments for phnX, phoD, ITS, 16S rRNA, entA, pqqE, and $a p h A$ genes (data not shown). Thus, the mean values of the three sampling periods were considered for each treatment (Table 5 ). The treatments showed a significant $(p<0.05)$ effect for the abundance of $p h n X, I T S, 16 S$ rRNA, and aphA genes in soil. It was highly significant ( $p<0.01)$ for the pqqE gene. The three compost treatments (Comp. P-Comp, P-Comp-Soil) promoted the proliferation of microorganisms harboring the phosphonatase $p h n X$ gene more significantly than the other treatments. The abundance of phnX gene was significantly lower in the NPK treatment. Soil fungi (ITS) were significantly more abundant in the NPK treatment (4.85 $10^{7} \mathrm{copies}^{-1}$ dry soil) than in the other treatments. This treatment was followed by the P-Comp-Soil/Comp/BPR group. The Control soil contained the lowest abundance of fungi (3.37 $10^{7}$ copies $\mathrm{g}^{-1} \mathrm{dry}$ soil), which was not significantly different from the Sorghum Straw treatment. In addition, the P-Comp-Soil treatment led to a significantly higher population of soil bacteria ( $5.1710^{8}$ copies of $16 S$ rRNA g ${ }^{-1}$ dry soil) than the Control, BPR, and the NPK treatments. However, it did not show significant differences with the Sorghum Straw, Comp, and P-Comp treatments. The soil of these three treatments contained similar numbers of total bacteria to the Control and the NPK treatments. Pyrroloquinoline quinone gene ( $p q q E)$, a co-factor of the gcd gene involved in phosphate solubilization, was significantly more abundant in soils treated with Comp, P-Comp-Soil, and NPK. The BPR treatment generated the lowest population of soil microbes with the $p q q E$ gene. Compared to the remaining six treatments, the P-Comp-Soil treatment significantly enhanced the copy numbers of the acid phosphatase gene (aphA) $\left(4.9810^{5}\right.$ copies $\mathrm{g}^{-1}$ dry soil). It was followed by the P-Comp treatment with $2.9110^{5}$ copies $\mathrm{g}^{-1}$ dry soil.

Table 5 showed a highly significant effect $(p<0.01)$ of the sampling period for the abundances of $p h n X$, phoD, and entA, and a significant effect $(p<0.05)$ for that of the $p q q E$ gene in soil. The overall soil's phosphonatase $p h n X$ gene increased with the cultivation progress to be significantly higher at harvest $\left(5.1810^{5}\right.$ copies $\mathrm{g}^{-1}$ of dry soil). A similar trend was observed for the siderophore enterobactin gene (ent $\left.A\right)$, although the overall abundance on the third sampling period ( $115^{\text {th }}$ day) was not significantly different from that on the first sampling period ( $52^{\text {nd }}$ day). In contrast, the alkaline phosphatase gene $(p h o D)$ and the $p q q E$ genes were significantly more abundant in soil on the $52^{\text {nd }}$ day than on the $93^{\text {rd }}$ and $115^{\text {th }}$ days. They decreased in number with the progress of the cultivation.

\section{Multivariate analysis: interactions of soil chemical and microbiological properties with sorghum yields}

Principal Component Analysis (PCA) was performed to understand the relationships between soil chemical and microbiological properties obtained during the three sampling periods and sorghum yields (dry biomass and dry grains) using the correlation matrix of Pearson. The factors loadings of different variables on PC1, PC2, PC3, PC4, PC5, and Eigenvalues (standard deviation, proportion variation, cumulative variation) were shown in Table S1. These first five components explained 81\% of the observed variation. However, PC1, PC2, and PC3, which accounted for $65.8 \%$ of the variation, were discussed. The cumulative variation of PC1 (29.5\%) and PC2 (22.7\%) was 52.2\% (Fig. 1a). PC1 and PC2 separated the variables into two groups. On the negative side of PC1, sorghum yields positively strongly correlated with total carbon (TC), acid phosphatase $(a p h A)$, alkaline phosphatase (phoD), total nitrogen (TN); and moderately with inorganic phosphorus-solubilizing microbes harboring the gcd and pqqE genes, phosphate specific transporter $p s t S$, exchangeable cations. These variables were strongly influenced by the first sampling period $\left(52^{\text {nd }}\right.$ day), and more by the P-Comp-Soil treatment during this period. The remaining variables clustered on the positive side of PC1 were highly influenced by the third sampling period $\left(115^{\text {th }}\right.$ day). Bray- $2 \mathrm{P}$ strongly positively correlated with total fungi and moderately with soil $\mathrm{pH}$, arbuscular mycorrhizal fungi (AMF), phosphonatase ( $p h n X)$. The P-Comp-Soil treatment strongly influenced the population soil AMF and phnX at harvest. When PC1 and PC2 are plotted, the second sampling ( $93^{\text {rd }}$ day) does not influence the distribution of variables. The highest factor loading in PC1 was obtained for the variable $\mathrm{pH}(0.343)$. It was followed by AMF $(0.283)$, phnX $(0.276)$, and total fungi $(0.218)$. The lowest factor loadings for negative correlation were -0.391 ( $T N$ ), -0.335 (phoD), -0.327 (TC), -0.313 (pqqE), -0.236 (aphA), while that of dry biomass yield and dry grain yield were $-0.153,-0.141$, respectively. The factor loadings on PC2 were all negative, with the lowest obtained for variabale exchangeable cations (-0.421), pstS (-0.355), 16S rRNA (-0.351). 
PC3 accounted for $13.6 \%$ of the variation, and when plotted with PC1 (29.5\%), both components explained $43.1 \%$ of the observed variration (Fig. 1b). On the PC1/PC3 plan, the three sampling periods were separated. The second sampling, which was not expressive on PC1/PC2, strongly influenced the dry biomass yield, dry grain yield, exchangeable cations, Bray-2 P, ent $\mathrm{A}$, and $\mathrm{C} / \mathrm{N}$, showing strong positive relationship of yield variables with exchangeable cations, with a strong positive influence of the P-Comp-Soil and NPK treatments, and moderate of P-Comp. Bray-2 P, $\mathrm{C} / \mathrm{N}$, and entA negatively correlated with yield variables and were positively correlated among them with the influence of BPR, sorghum straw, and Comp. The third sampling ( $115^{\text {th }}$ day) did not influence the yield variables. However, total bacteria and fungi were positively related to $\mathrm{P}$ Comp-Soil, while P-Comp, mainly influenced the $p h n X, \mathrm{AMF}$, and the $\mathrm{pH}$. Dry biomass yield and dry grain yield of sorghum showed loading factors of $0.538,0.533$, respectively, on PC3. They were followed by total fungi $(0.390)$ and total bacteria (0.195).

The Spearman's correlation (Table S2) confirmed that sorghum biomass was moderately negatively correlated with entA, AMF, pH, and Bray2_P, and moderately positively correlated with total nitrogen, total carbon, and exchangeable cations. The grain yield was moderately negatively correlated with AMF, pH, and Bray2_P and positively correlated with total bacteria (16S rRNA), total nitrogen, total carbon, and exchangeable cations. Among the other existing interactions, we noticed that the abundance of soil bacteria was moderately positively correlated with AMF, pH, and exchangeable cations but weakly with $\mathrm{C} / \mathrm{N}$. The soil fungi moderately negatively correlated with $p q q E$ and weakly negatively correlated with nitrogen and carbon. It correlated moderately positively with AMF, weakly with $\mathrm{pH}$, and strongly with bacteria. The phosphonatase phnX gene strongly positively correlated with $\mathrm{AMF}$ and $\mathrm{pH}$, moderately positively with total fungi and total bacteria, but moderately negatively correlated with $p h o D$, and $p q q E$.

\section{Discussion}

This study evaluated sorghum production under different organo-mineral amendments and assessed their influence on soil chemical and microbiological properties. Except for the control, all treatments were designed to contain the same amount of total P. Triple Super Phosphate supplied the required amount of $\mathrm{P}$ in the NPK treatment, while the applied rate of P-Comp-Soil (1.34 $\mathrm{t} \mathrm{ha}^{-1}$ ) was enough to provide the necessary $90 \mathrm{~kg} \mathrm{P} \mathrm{ha}^{-1}$. The content of total $\mathrm{P}$ was the same in all treatments (except the control), but the available P differed. Also, treatments had the same total concentrations of nitrogen and potassium.

The P-Comp-Soil treatment gave sorghum yields comparable to the chemical treatment NPK and significantly higher than the other treatments. P-Comp-Soil contained an initial higher amount of available P, justifying why BPR was not added to leverage to the required amount of $90 \mathrm{~kg} P$ $\mathrm{ha}^{-1}$. Possibly, the ambient available $\mathrm{P}$ level in this treatment and the supply of a loop of P-solubilizing microbes, and exchangeable cations may have created an environment favorable for enhanced uptake of nutrients by sorghum, leading to better plant growth. Interestingly, P-Comp-Soil gave a significantly higher number of good ears (filled with grains) compared with the NPK treatment. A similar result was reported by Asai et al. (2021) in rice, where farmyard manure application increases spikelet fertility and grain yield on phosphorus-deficient conditions in Madagascar highlands. Other works have highlighted the significant contribution of improved P uptake in increasing grain yields (Rakotoarisoa et al. 2020; Rakotoson and Tsujimoto 2020).

The Burkina phosphate rock used in this study contains about 34.39\% CaO and $0.18 \% \mathrm{MgO}$ (Nakamura et al. 2015). Therefore, the increased exchangeable cations in soils amended with P-Comp-Soil, particularly calcium and magnesium (data not shown), could be derived from the enhanced microbial-mediated phosphate solubilization during composting, concomitantly releasing more cations in the compost product and in soil. Sarr et al. (2020) found in this type of compost a higher number of phosphate-solubilizing fungi and phosphatase-releasing microbial genes. Phosphate-solubilizing bacteria and fungi (Liu et al. 2018; Liang et al. 2020; Jacoby et al. 2017) increase phosphate availability in the soil and facilitate its uptake by plants (Thakur et al. 2014; Suleman et al. 2018; Chungopast et al. 2021). Soil inoculation with Aspergillus terreus and Penicillium pinophilum has been shown to increase the phosphate availability in soil and the biomass yields of sorghum (Steiner et al. 2016). In the present study, soils amended with P-Comp-Soil contained a significantly higher population of microbes harboring the $p q q E$ and $g c d$ (especially during the first sampling) genes that are involved in inorganic phosphorus solubilization (Liang et al. 2020; Suleman et al. 2018; Zeng et al. 2016). It likely indicates an early expression of $g c d$ with the support of the co-factor pqqE gene and the secretion of organic acids (not determined) to further enhance the soil phosphate solubilization. These early biogeochemical nutrient transformations are essential to provide the crop with nutrients for its establishment, which significantly influences the yields at harvest. Fig. 1 confirmed that soil properties strongly influence sorghum yields in the early growth stage. Wan et al. (2020) mainly associated the solubilization of $\mathrm{Ca}_{3}\left(\mathrm{PO}_{4}\right)_{2}, \mathrm{FePO}_{4}$, and $\mathrm{AlPO}_{4}$ in soil by Acinetobacter pittii to the expression of the gcd gene, which releases organic acids, predominantly gluconic acid (Xiao et al. 2009 ; Zeng et al. 2016). In addition, P-Comp-Soil-treated soils showed a significantly higher abundance of the phosphate-specific transporter ( $p s t S$ ) and acid phosphatase ( $a p h A)$ genes, as well as a significant abundance of total bacteria and fungi. Acid phosphatases (aphA in this study), together with phosphonatases $(p h n X)$, alkaline phosphatases $(p h o D)$, and phytases $(a p p A)$, encode organic phosphate mineralization enzymes (Liu et al. 2018; Tanuwidjaja et al. 2020). The organic phosphate forms are represented mainly by phytate (Sing and Satyanarayana 2011). Besides this dominant organic phosphorus form, secondary forms including phosphate monoesters, phosphate diesters, phosphate triesters, phospholipids, and nucleic acids also constitute organic phosphate stores (Rodríguez and Fraga 1999). The mineralization of these organic materials releases 
plant-available nutrients (Jacoby et al. 2017). Conversely, organic fertilizers boost soil microbial activity by providing an energy source to microorganisms and enhance plant growth by providing a broad array of nutrients (Mokgolo et al. 2019; Wu et al. 2020).

Interestingly, the available P level was lower in the P-Comp-Soil-treated soil at harvest, similarly to NPK and P-Comp. Such a result could be explained by a better $\mathrm{P}$ uptake in these treatments during cultivation. As reported above and confirmed by the PCA (Fig. 1), the P-Comp-Soil, which contained a higher abundance of several microbial genes, also led to the best sorghum growth. Sahib et al. (2020) also found a similar result that the richness of rhizobacterial species improves sorghum growth and nutrient synergism in nutrient-poor soil and that soil nutrient contents were generally lower at higher plant-associated rhizobacterial diversity. The significant increase of the microbial phosphate specifictransporter (pstS) in the P-Comp-Soil-treated soil since the early growth stage (52nd day) (Fig. 1a) and in the P-Comp at harvest (115th day) supports a good $\mathrm{P}$ uptake and transport of available phosphorus in these treatments (Table 3). Rao and Torriani (1990) indicated that the phosphate import system in bacteria is activated when the external phosphate concentration is equal to or above $20 \mu \mathrm{M}$. Part of the phosphorus immobilized in microbial cells can be solubilized and reused by the living organism.

On the other hand, the symbiosis of arbuscular mycorrhizal fungi with plants reinforces plant tolerance to biotic and abiotic stresses (Sharma et al. 2021) and improves nutrient uptake, especially phosphorus and nitrogen (Sun et al. 2018; Begum et al. 2019). Arbuscular mycorrhizal fungi have been reported to improve the growth and production of several crops, including wheat, rice, maize (Zhang et al. 2019), and sorghum (Kaur et al. 2020; Watts-Williams et al. 2019). The present work found a higher abundance of AMF population in the rhizosphere soil of sorghum plants fertilized with P-Comp-Soil and P-Comp compared with the control, sorghum straw, Comp, BPR, and NPK treatments, especially during the early growth stage (first sampling). These AMF may be a mixture of AMF spores and germinated AMF mycelia and hyphae in connexion with the sorghum roots, creating a mycorrhizal network. Although we did not determine AMF spores' density, they are known to decrease during root growth and increase during root inactivity and senescence (Songachan et al. 2011). An intense mycorrhizal network during plant growth enhances the transfer of water and nutrients from the soil to the plant (Smith and Smith 2011). Therefore, the higher sorghum grain yield (0.82 $t$ $\mathrm{ha}^{-1}$ ) and biomass $\left(3.87 \mathrm{t} \mathrm{ha}^{-1}\right)$ of the P-Comp-Soil treatment, comparable to that of the fertilizer NPK (Table 1), likely resulted in parts from an improved nutrient availability (phosphate, nitrogen, cations etc.) and uptake, facilitated by the activity of soil microorganisms (AMF and Psolubilizing microbes). However, the strong positive influence on AMF in the third sampling period (harvest) when the soil was collected in almost dry condition (Fig. 1a, 1b) indicates that AMF at this period already was in spore condition and may no more be active in nutrient uptake and transfer to sorghum plant.

The decrease in available P along the cultivation period in P-Comp-Soil and NPK soils, which gave the higher sorghum yields, partly explain the negative relationships between yields and available P (Bray-2 P) as shown by the PCA result (Fig. 1a, 1b). The strong relationship between Bray-2 $\mathrm{P}$ and the BPR, Sorghum Straw, and Comp treatments, especially during the second and third samplings (Fig. 1), showed that available P was still high at harvest in the soil amended with these treatments. In the Sorghum Straw, Comp, and BPR treatments, we added more Burkina Faso Phosphate Rock (BPR) during treatment application to reach the desired rate of $90 \mathrm{~kg} \mathrm{P} \mathrm{ha}^{-1}$ as in the chemical fertilizer (NPK) treatment. Although BPR has low agronomic effectiveness due to its weak solubility (Nakamura et al. 2020; Fukuda et al. 2021), the soil treated with Sorghum Straw, Comp, and BPR contained a high amount of Bray2-P at harvest (Table 3). The applied phosphate rock in these three treatments may have been gradually solubilized but absorbed poorly by sorghum roots, probably due to environmental factors such as soil concretion and limited soil moisture, justifying the lower yields obtained in these treatments compared to P-Comp-Soil and NPK. The sub-Saharan African PRs effectively achieved high performance in lowland rice, following direct application (Nakamura et al. 2013). We did not obtain a similar result in the present study on upland sorghum cultivation. It has been revealed a depressive effect of the initial PR direct application under water-limited conditions such as upland cultivation. However, the initial P in soils may be enhanced and PR application and be effective as a residual effect during subsequent cultivations (Nakamura et al. 2016), which may be the case in our sorghum straw, Comp, and BPR treatments. The Control and NPK treatments differed only by the absence of $\mathrm{P}$ application in control. In this situation, we observed a drop of biomass yields in control compared to NPK by $34 \%$ and a drop of grain yield by $27 \%$, clearly showing the importance of phosphorus nutrition in the studied environment of Burkina Faso and sub-Saharan Africa in general. Also, the sorghum biomass and grain yield in the control dropped by $25 \%$ and $23 \%$, respectively, compared with P-Comp-Soil, that contained a significantly higher available P level. Enhanced phospho-composting with microbial sources is an alternative to produce low-cost organo-mineral fertilizers that achieve higher sorghum yields during the first season in upland cultivation systems. However, the strong positive spearman's correlations between sorghum biomass yield, total nitrogen, and total carbon (Table S2) indicated that other than $\mathrm{P}$ and exchangeable cations, nitrogen and carbon are other essential nutrients for sorghum growth in the studied environment. Moreover, the negative correlation between yields and $\mathrm{pH}$ revealed that a better sorghum production is achieved when the acidic soil $\mathrm{pH}$ tends to neutrality.

\section{Conclusion}

This study highlighted the importance of soil amendment in sub-Saharan Africa to support crop growth, given the overall low soil fertility in many croplands. In Burkina Faso, where access to chemical fertilizers is limited, we evaluated the combination of several organo-mineral fertilizers on sorghum production. Only P-Comp-Soil gave sorghum yields among the organic treatments like that of the chemical fertilizer NPK. This result is 
explained by the higher available P concentration in the Burkina Faso phosphate rock-enriched compost made by supplementing rhizosphere soil during the process. P-Comp-Soil also harbors higher abundances of microbial genes involved in the solubilization and phosphate mobilization ( $g c d, p q q E$, phnX, aphA, AMF, pstS), total bacteria, and boosts microbial activities in soil upon application. Other than $\mathrm{P}$, the multivariate analysis showed the essential contribution of nitrogen, carbon, and exchangeable cations in sorghum production, indicating the importance of organic amendment in sub-Saharan African soils. In addition, we understood through this study that the direct application of low-grade phosphate rocks might not be efficient in the upland cultivation systems in Africa, where water is generally limited. Instead, soils may be replenished with organomineral materials such as improved BPR-enriched composts, with the supplement of P-solubilizing microbial sources during the composting process. P-Comp-Soil fertilizers are of low cost and help restore soil chemical and microbiological fertility for better crop production.

\section{Abbreviations}

SS: Sorghum Straw

BPR: Burkina Faso Phosphate Rock

Comp: Compost

P-Comp: BPR-enriched compost

P-Comp-Soil: BPR plus rhizosphere soil-enriched compost

AMF: Arbuscular Mycorrhizal Fungi

TN: Total Nitrogen,

P: Phosphorus

K: Potassium

TC: Total Carbon

PCA: Principal Component Analysis

ANOVA: Analysis of variance

TSP: Triple Super Phosphate

SE: Standard Error

Df: Degree of freedom

DMRT: Duncan Multiple Range Test.

LSD: Least Significant Difference

DBY: Dry Biomass Yield

DGY: (Dry Grain Yield

Exch._cat. : Exchangeable cations

\section{Declarations}

\section{Acknowledgments}

We express our sincere gratitude to JICA and JST for funding this research through SATREPS project. We are very thankful to Dr. Fujio Nagumo of JIRCAS, leader of the SATREPS project, for his comments and guidance during this work. We appreciate the staff of INERA their valuable support in the field and laboratory work in Burkina Faso, and JIRCAS's Soil Team for soil chemical analysis. Soil samples were imported following the approval procedures of the Ministry of Agriculture, Forestry, and Fisheries of Japan.

\section{Funding}


This research was funded by the Japan Science and Technology Agency (JST) and the Japan International Cooperation Agency (JICA) through the Burkina SATREPS (Science and Technology Research Partnerships) project No JPMJSA1609.

\section{Compiting interests}

The authors have no conflicts of interest to declare that are relevant to the content of this article.

\section{Author contributions}

PSS, NAZ, EC, and SN: conceptualization. PSS, EBT, SI, NAZ, and AS: methodology. PSS, MT, EBT, NB, IJOB, FT: validation. AS, EBT, MT, SI, and PSS: formal analysis. AS, IJOB, MT, NB, PSS, EBT, FT, and ANZ: investigation. PSS, AS, ETB, and SN: data curation. AS: writing-original draft preparation. PSS and AS: writing-review and editing. PSS, EBT, NAZ, SI, NB, FI, and AS: visualization. SN-PSS: funding acquisition. All authors have read and agreed to the published version of the manuscript.

\section{Data Availability}

The datasets generated during and/or analysed during the current study are available from the corresponding author on reasonable request

\section{Supplementary Information (SI)}

Some data are summarized in supplementary Tables (see Table S1, Table S2)

\section{References}

1. Anand K, Kumari B, Mallick MA (2016) Phosphate Solubilizing Microbes: An effective and alternative approach as biofertilizers. Int J Pharm Pharm Sci 8:37-40.

2. Asai H, Rabenarivo M, Andriamananjara A, Tsujimoto Y, Nishigaki T, Takai T, Rakotoson T, Rakotoarisoa NM, Razafimbelo T (2021) Farmyard manure application increases spikelet fertility and grain yield of lowland rice on phosphorus-deficient and cool-climate conditions in Madagascar highlands. Plant Prod Sci doi: 10.1080/1343943X.2021.1908150.

3. Bationo A, Mukwunye AU (1991) Alleviating soil fertility constraints to increase crop production in West Africa. Fert Res 29:95-115.

4. Begum N, Qin C, Ahanger MA, Raza S, Khan MI, Ashraf M et al (2019) Role of arbuscular mycorrhizal fungi in plant growth regulation: Implications in abiotic stress tolerance. Front Plant Sci 10:1068. doi: 10.3389/fpls.2019.01068.

5. Bergkemper F, Kublik S, Lang F, Krüger J, Vestergaard G, Schloter M et al (2016) Novel ologonucleotide primers reveal a high diversity of microbes which drives phosphorus turnover in soil. J Microbiol Methods 125:91-97. doi: 10.1016/j.mimet.2016.04.011.

6. Biswas DR, Narayanasamy G (2006) Rock phosphate enriched compost: an approach to improve low-grade Indian rock phosphate. Bioresour Technol 97:2243-2251. doi: 10.1016/j.biortech.2006.02.004.

7. Bray RH, Kurtz, LT (1945) Determination of total organic and available forms of phosphorus in soils. Soil

8. Sci 59:39-45. doi: 10.1097/00010694-194501000-00006.

9. Butterbach-Bahl K, Nemitz E, Zaehle S, Billen G, Boeckx P, Erisman JW, Garnier J et al (2011) Nitrogen as a threat to the European greenhouse gas balance. In: Sutton MA et al (eds.) The European nitrogen assessment: sources, effects, and policy perspectives (pp. 434-462) Cambridge, UK, Cambridge University Press.

10. Chen W, Yang F, Zhang L, Wang J (2015) Organic acid secretion and phosphate solubilizing efficiency of Pseudomonas PSB12: effects of phosphorus forms and carbon sources. Geomicrobiol J 33:870-877. doi: 10.1080/01490451.2015.1123329.

11. Choi O, Kim J, Kim JG, Jeong Y, Moon JS, Park CS, et al. (2008) Pyrroloquinonline quinone is a plant growth promotion factor produced by Pseudomonas fluorescens Plant Physiol 146:657-668. doi: 10.1104/pp.107.112748.

12. Chungopast S, Thongjoo C, Islam AKMM, Yeasmin S (2021) Efficiency of phosphate-solubilizing bacteria to address phosphorus fixation in Takhli soil series: a case of sugarcane cultivation, Thailand. Plant Soil 460:347-357.

13. Fukuda M, Soma DM, Iwasaki S, Nakamura S, Kanda T, Ouattara K, Nagumo F (2021) Site-specific responses of lowland rice to acidulated and calcined phosphate rock fertilizers in the Center-West region of Burkina Faso. PloS One 19;16(4):e0250240. doi: 10.1371/journal.pone.0250240. eCollection 2021.

14. Gemenet DC, Leiser WL, Beggi F, Herrmann LH, Vadez V, Rattunde HFW, et al. (2016) Overcoming phosphorus deficiency in West African pearl millet and sorghum production systems: Promising options for crop improvement. Front Plant Sci 7:10. doi: 10.3389/fpls.2016.01389.

15. Ghosh P, Rathinasabapathi B, Ma LQ (2015) Phosphorus solubilization and plant growth enhancement by arsenic-resistant bacteria. Chemos 134, 1-6. doi: 10.1016/j.chemosphere.2015.03.048. 
16. Hammer O, Harper DAT, Ryan PD (2001) PAST. Paleontological statistics software Package for education and data analysis. Palaeontol Electron 4:9.

17. Ikazaki K, Nagumo F, Simporé S, Barro A (2018) Soil toposequence, productivity, and a simple technique to detect petroplinthites using ground-penetrating radar in the Sudan Savanna. Soil Sci Plant Nutr 64:623-631. https://doi.org/10.1080/00380768.2018.1502604.

18. Ingle KP, Padole DA (2017) Phosphate solubilizing microbes: An overview. Int J Curr Microbiol Appl Sci 6:844-852. doi: 20546/ijcmas.2017.601.099.

19. Jacoby R, Peukert M, Succurro A, Koprivova A, Kopriva S (2017) The role of soil microorganisms in plant mineral nutrition-current knowledge and future directions. Front Plant Sci 8:1617. doi:10.3389/fpls.2017.01617.

20. Kaur J, Chavana J, Soti P, Racelis A, Kariyat R (2020) Arbuscular mycorrhizal fungi (AMF) influences growth and insect community dynamics in Sorghum-sudangrass (Sorghum x drummondii). Arthrop-Plant Inter. doi: 10.1007/s11829-020-09747-8.

21. Lee J, Lee S, Young JPW (2008) Improved PCR primers for the detection and identification of arbuscular mycorrhizal fungi: PCR primers for arbuscular mycorrhizal fungi. FEMS Microbiol Ecol 65:339-349. doi: 10.1111/j.1574-6941.2008.00531.x.

22. Liang JL, Liu J, Jia P, Yang T, Zeng Q, Zhang S, et al. (2020) Novel phosphate-solubilizing bacteria enhance soil phosphorus cycling following ecological restoration of land degraded by mining. ISME J 14:1600-1613. doi: 10.1038/s41396-020-0632-4.

23. Liu J, Cade-Menun BJ, Yang J, Hu Y, Liu CW, Tremblay J, et al. (2018) Long-term land use affects phosphorus speciation and the composition of phosphorus cycling genes in agricultural soils. Front Microbiol 9:1643. doi: 10.3389/fmicb.2018.01643.

24. Lompo F, Bationo A, Sedogo MP, Bado VB, Hien V, Ouattara B (2018) Role of local agro-minerals in mineral fertilizer recommendations for crops: examples of some West Africa phosphate rocks. In: Bationo A et al (eds) Improving the profitability, sustainability and efficiency of nutrients through site specific fertilizer recommendations in West Africa agro-ecosystems (pp. 157-180) Springer International Publishing.

25. Mokgolo MJ, Mzezewa J, Odhiambo JJ (2019) Poultry and cattle manure effects on sunflower performance, grain yield and selected soil properties in Limpopo Province South Africa. S Afr J Sci 115, 1-7.

26. Murphy J, Riley JP (1962) A modified single solution method for the determination of phosphate in natural waters. Anal Chim Acta 27:31-36. https://doi.org/10.1016/S0003-2670(00)88444-5.

27. Nakamura S, Saidou S, Barro A, Jonas D, Fukuda M, Kanda T, Nagumo F (2020) Kodjari phosphate rock for rain-fed lowland rice production in the Sudan Savanna, Burkina Faso. Trop Agr Develop 64: 97-106.

28. Nakamura S, Dukuda M, Issaka RN, Dzomeku IK, Buri MM, Avornyo VK, Adjei EO, Awuni JA, Tobita S (2016) Residual effects of direct application of Burkina Faso phosphate rock on rice cultivation in Ghana. Nutr Cycl Agroecosyst 106:47-59.

29. Nakamura S, Iwai T, Toriyama K, Tobita S, Matsunaga R, Fukuda M, et al. (2015) Solubilization of Burkina Faso phosphate rock through calcination method. Jap J Soil Sci Plant Nutr 86:535-539. doi: 10.20710/dojo.86.6_534.

30. Nakamura S, Fukuda M, Nagumo F, Tobita S (2013) Potential utilization of local phosphate rocks to enhance rice production in sub-Saharan Africa. JARQ 47:353-363.

31. Ouédraogo E, Mando A, Zombré NP (2001) Use of compost to improve soil properties and crop productivity under low input agricultural system in West Africa. Agric Ecosyst Environ 84:259-266.

32. R Core Team (2020) R: A language and environment for statistical computing. R Foundation for Statistical Computing, Vienna, Austria

33. Rahman KMA, Zhang D (2018) Effects of fertilizer broadcasting on the excessive use of inorganic fertilizers and environmental sustainability. Sustain. 10:759. doi: 10.3390/su10030759.

34. Rakotoarisoa NM, Tsujimoto Y, Oo AZ (2020) Dipping rice seedlings in P-enriched slurry increases grain yield and shortens days to heading on P-deficient lowlands in the central highlands of Madagascar. Field Crops Res 254(4):107806, doi: 10.1016/j.fcr.2020.107806.

35. Rakotoson T, Tsujimoto Y (2020) Pronounced effect of farmyard manure application on P availability to rice for paddy soils with low total C and low pH in the central highlands of Madagascar. Plant Prod Sci doi: 10.1080/1343943X.2020.1740601.

36. Rao NN, Torriani A (1990) Molecular aspects of phosphate transport in Escherichia coli. Mol. Microbiol. 4:1083-1090. doi: 10.1111/j.13652958.1990. tb00682.x.

37. Rodríguez H, Fraga R (1999) Phosphate solubilizing bacteria and their role in plant growth promotion. Biotechnol Adv 17:319-339. doi: 10.1016/S0734-9750(99)00014-2.

38. Sahib MR, Pervaiz ZH, Williams MA, Saleem M, DeBolt S (2020) Rhizobacterial species richness improves sorghum growth and soil nutrient synergism in a nutrient-poor greenhouse soil. Sci Rep 10:15454. https://doi.org/10.1038/s41598-020-72516-3.

39. Salem WM, Sayed WF, Abdel-Fatah H, Neamat HH (2012) Assessment of compost for suppression of Fusarium oxysporum and improving Zea mays and Hibiscus sabdariffa resistance to wilt diseases. Afr J Biotechnol 11:13403-13414. doi: 10.5897/AJB12.1252. 
40. Sarr PS, Tibiri EB, Fukuda M, Zongo AN, Compaore E, Nakamura S (2020) Phosphate-solubilizing fungi and alkaline phosphatase trigger the P solubilization during the co-composting of sorghum straw residues with Burkina Faso phosphate rock. Front Environ Sci 8:559195. doi: 10.3389/fenvs.2020.559195.

41. Shang L, Wan L, Zhou X, Li S, Li X (2020) Effects of organic fertilizer on soil nutrient status, enzyme activity, and bacterial community diversity in Leymus chinensis steppe in Inner Mongolia, China. Plos One 15:e0240559. doi: 10.1371/journal.pone.0240559.

42. Sharma K, Gupta S, Thokchom SD, Jangir P, Kapoor R (2021) Arbuscular mycorrhiza-mediated regulation of polyamines and aquaporins during abiotic stress: deep insights on the recondite players. Front Plant Sci 12:642101. doi: 10.3389/fpls.2021.642101.

43. Singh B, Satyanarayana T (2011) Microbial phytases in phosphorus acquisition and plant growth promotion. Physiol Mol Biol Plants 17:93103. doi: 10.1007/s12298-011-0062-x.

44. Smith SE, Smith FA (2011) Role of arbuscular mycorrhizas in plant nutrition and growth: a new paradigm from cellular to ecosystems scales. An Rev Plant Biol 62:227-2250.

45. Songachan L, Lungdoh I, Highland K (2011) Colonization of arbuscular mycorrhizal fungi in moderately degraded sub-tropical forest stands of Meghalaya, Northern India. J Agric Technol 7:1673-1684.

46. Souchie EL, Saggin-Júnior OJ, Silva EMR, Campello EFC, Azcón R, Barea JM (2006) Communities of P-solubilizing bacteria, fungi and arbuscular mycorrhizal fungi in grass pasture and secondary forest of Paraty, RJ - Brazil. An Acad Bras Ciênc 78:183-193. doi: 10.1590/S0001-37652006000100016.

47. Steiner F, Lana MC, Zoz T (2016) Phosphate solubilizing fungi enhance the growth and phosphorus uptake of sorghum plants. Rev Bras Milho E Sorgo 15:30-38. doi: 10.18512/1980-6477/rbms.v15n1p30-38.

48. Suleman M, Yasmin S, Rasul M, Yahya M, Atta BM, Mirza MS (2018) Phosphate solubilizing bacteria with glucose dehydrogenase gene for phosphorus uptake and beneficial effects on wheat. Plos One 13:e0204408. doi: 10.1371/journal.pone.0204408.

49. Sun Z, Song J, Xin X, Xie X, Zhao B (2018) Arbuscular mycorrhizal fungal 14-3-3 proteins are involved in arbuscule formation and responses to abiotic stresses during AM symbiosis. Front Microbiol 9:91. doi: 10.3389/fmicb.2018.00091.

50. Tanuwidjaja I, Vogel C, Pronk GJ, Schöler A, Kublik S, Vestergaard G, et al. (2020) Microbial key players involved in P turnover differ in artificial soil mixtures depending on clay mineral composition. Microb Ecol 81:897-907. doi: 10.1007/s00248-020-01635-1.

51. Thakur D, Kaushal R, Shyam V (2014) Phosphate solubilising microorganisms: role in phosphorus nutrition of crop plants-A review. Agric Rev 35:159-171. doi: 10.5958/0976-0741.2014.00903.9.

52. Vollset SE, Goren E, Yuan CW, Cao J, Smith AE, Hsiao T, et al. (2020) Fertility, mortality, migration, and population scenarios for 195 countries and territories from 2017 to 2100: a forecasting analysis for the Global Burden of Disease Study. Lancet 396:1285-1306. doi: $10.1016 /$ S0140-6736(20)30677-2.

53. Vu V (2011) ggbiplot: A ggplot2 Based Biplot. R Package version 055.

54. Wan W, Qin Y, Wu H, Zuo W, He H, Tan J, et al. (2020) Isolation and characterization of phosphorus solubilizing bacteria with multiple phosphorus sources utilizing capability and their potential for lead immobilization in soil. Front Microbiol 11:752. doi: 10.3389/fmicb.2020.00752.

55. Watts-Williams SJ, Emmett BD, Levesque-Tremblay V, MacLean AM, Sun X, Satterlee JW, Fei Z, Harrison MJ (2019) Diverse Sorghum bicolor accessions show marked variation ingrowth and transcriptional responses to arbuscular mycorrhizal fungi. Plant Cell Environ 42:1758-1774. doi: $10.1111 /$ pce. 13509 .

56. Wickham H (2016) ggplot2: Elegant Graphics for Data Analysis, Springer-Verlag New York. Available at: https://ggplot2.tidyverse.

57. Wu L, Jiang Y, Zhao F, He X, Liu H, Yu K (2020) Increased organic fertilizer application and reduced chemical fertilizer application affect the soil properties and bacterial communities of grape rhizosphere soil. Sci Rep 10:9568. https://doi.org/10.1038/s41598-020-66648-9.

58. WRB (World Reference Base) (2006) World reference base for soil resources: a framework for international classification, correlation, and communication. World Soil Resources Reports No. 103, FAO, Rome, 132 pp.

59. Xiao C, Chi R, He H, Qiu G, Wang D, Zhang W (2009) Isolation of phosphate-solubilizing fungi from phosphate mines and their effect on wheat seedling growth. Appl Biochem Biotechnol 159:330-342. doi: 10.1007/s12010-009-8590-3.

60. Yi Y, Huang W, Ge Y (2008) Exopolysaccharide: a novel important factor in the microbial dissolution of tricalcium phosphate. World J Microbiol Biotechnol 24:1059-1065. doi: 10.1007/s11274-007-9575-4.

61. Zhang S, Lehmann A, Zheng W, You Z, Rillig MC (2019) Arbuscular mycorrhizal fungi increase grain yields: A meta-analysis. New Phytol 222:543-555.

62. Zeng Q, Wu X, Wen X (2016) Effects of soluble phosphate on phosphate-solubilizing characteristics and expression of gcd gene in Pseudomonas frederiksbergensis JW-SD2. Curr Microbiol 72:198-206. doi: 10.1007/s00284-015-0938-z.

63. Zougmoré BR (2003) Integrated water and nutrient management for sorghum production in semi-arid Burkina Faso.Wageningen University, ISBN 90-5808-906-1.205 pp. 


\section{Tables}

Table 1 Sorghum yields

\begin{tabular}{llll}
\multirow{2}{*}{ Treatments } & Dry biomass & Dry grains & \multirow{2}{*}{$\%$ good ears } \\
\cline { 2 - 3 } & t ha ${ }^{-1}$ & & \\
\cline { 1 - 2 } Control & $2.91 \mathrm{bc}$ & $0.63 \mathrm{bc}$ & $55.03 \mathrm{c}$ \\
\hline SS & $2.34 \mathrm{c}$ & $0.48 \mathrm{c}$ & $57.66 \mathrm{bc}$ \\
\hline Comp & $2.27 \mathrm{c}$ & $0.45 \mathrm{c}$ & $61.21 \mathrm{abc}$ \\
\hline P-Comp & $2.59 \mathrm{c}$ & $0.61 \mathrm{bc}$ & $67.37 \mathrm{ab}$ \\
\hline P-Comp-Soil & $3.87 \mathrm{ab}$ & $0.82 \mathrm{ab}$ & $72.23 \mathrm{a}$ \\
\hline BPR & $2.29 \mathrm{c}$ & $0.49 \mathrm{c}$ & $54.56 \mathrm{c}$ \\
\hline NPK & $4.43 \mathrm{a}$ & $0.86 \mathrm{a}$ & $72.51 \mathrm{a}$ \\
\hline Trait Sign. & $*$ & $*$ & $*$ \\
\hline SE & 0.49 & 0.09 & 5.01 \\
\hline Error df & 24 & 24 & 24
\end{tabular}

Within the same column, values assigned with the same letter are not significantly different according to the Student-Newman-Keuls (SNK) test at the $5 \%$ probability level. Parameter values assigned different letters differ significantly $(*)$ at $p<0.05$. Control $=$ without phosphate or compost addition, SS = sorghum straw, Comp = sorghum straw-based compost, $\mathrm{P}$-Comp = sorghum straw-based compost + BPR, P-Comp-soil = compost made from sorghum straw, BPR and sorghum rhizosphere soil, BPR = Burkina phosphate rock, Sign. Trait = significance trait, SE = Standard error, Error $\mathrm{df}=$ Error degree of freedom

Table 2 Physicochemical parameters of the rhizosphere soil based on two-way ANOVA 


\begin{tabular}{|c|c|c|c|}
\hline \multirow[t]{2}{*}{ Variables } & $\mathrm{TN}$ & $\mathrm{TC}$ & Sum Exch. Cat. \\
\hline & \multicolumn{2}{|c|}{$\mathrm{mg} \mathrm{kg}^{-1}$ dry soil } & cmolc kg-1 dry soil \\
\hline \multicolumn{4}{|c|}{ Treatment' effect (DMRT-based comparison) } \\
\hline Control & $0.338 \mathrm{~cd}$ & 2.976 & $0.876 \mathrm{c}$ \\
\hline SS & $0.331 \mathrm{~d}$ & 3.089 & $0.938 \mathrm{~b}$ \\
\hline Comp & $0.355 a b$ & 3.123 & $0.985 \mathrm{~b}$ \\
\hline P-Comp & $0.365 \mathrm{ab}$ & 3.212 & $0.963 \mathrm{~b}$ \\
\hline P-Comp-Soil & $0.370 \mathrm{a}$ & 3.266 & 1.079 a \\
\hline BPR & $0.335 \mathrm{~d}$ & 2.954 & $0.870 \mathrm{c}$ \\
\hline NPK & 0.352 bc & 3.127 & $0.949 \mathrm{~b}$ \\
\hline Sign. Trait & * & ns & * \\
\hline SE & 0.007 & 0.098 & 0.026 \\
\hline Error df & 83 & 83 & 81 \\
\hline $\operatorname{LSD}_{0.05}(n=15)$ & 0.022 & 0.301 & 0.08 \\
\hline
\end{tabular}

Sampling period's effect (LSD-based comparison)

\begin{tabular}{llll}
\hline $52^{\text {nd }}$ day & $0.389 \mathrm{a}$ & $3.426 \mathrm{a}$ & 0.972 \\
\hline $93^{\text {rd }}$ day & $0.336 \mathrm{~b}$ & $2.898 \mathrm{~b}$ & 0.899 \\
\hline $115^{\text {th }}$ day & $0.323 \mathrm{~b}$ & $2.997 \mathrm{~b}$ & 0.983 \\
\hline Sign. Trait & $* *$ & $\star *$ & $\mathrm{~ns}$ \\
\hline $\mathrm{LSD}_{0.05}(\mathrm{n}=35)$ & 0.034 & 0.258 & 0.16
\end{tabular}

Within the same column, values assigned the same letter are not significantly different according to the Student-Newman-Keuls (SNK) test at the $5 \%$ probability level. Parameter values assigned different letters differ highly significantly $(* *)$ at $p<0.01$, and significantly $(*)$ at $p<0.05$, ns $=$ not significant at $p<0.05$. Control = without phosphate or compost addition, $\mathrm{SS}=$ sorghum straw, Comp = sorghum straw-based compost, $\mathrm{P}$ Comp = sorghum straw-based compost + BPR, P-Comp-soil = compost made from sorghum straw, BPR and sorghum rhizosphere soil, BPR = Burkina phosphate rock, Sign. Trait = significance trait, SE $=$ Standard error, Error df = Error degree of freedom, TC $=$ Total carbon, $\mathrm{TN}=\mathrm{Total}$ nitrogen, Exch. Cat. = exchangeable cations $(\mathrm{Ca}, \mathrm{K}, \mathrm{Mg}, \mathrm{Na}), \mathrm{DMRT}=$ Duncan Multiple Range Test, LSD = Least Significant difference.

Table 3 Physicochemical parameters of the rhizosphere soil based on one-way ANOVA 


\begin{tabular}{|c|c|c|c|c|c|c|c|c|c|}
\hline \multirow[t]{3}{*}{ Treatments } & \multicolumn{3}{|l|}{$\mathrm{pH}$} & \multicolumn{3}{|l|}{$\mathrm{C} / \mathrm{N}$} & \multicolumn{3}{|c|}{ Bray2-P (mg kg-1 dry soil) } \\
\hline & $52^{\text {nd }}$ & $93^{\text {rd }}$ & $115^{\text {th }}$ day & $52^{\text {nd }}$ & $93^{\text {rd }}$ & $115^{\text {th }}$ & $52^{\text {nd }}$ & $93^{\text {rd }}$ & $115^{\text {th }}$ \\
\hline & day & day & & day & day & day & day & day & day \\
\hline \multicolumn{10}{|c|}{ Treatment's effect (DMRT-based comparison) } \\
\hline Control & $5.34 \mathrm{c}$ & $5.53 \mathrm{bc}$ & 5.95 & 8.66 & $8.73 \mathrm{~b}$ & 9.05 & $09.39 \mathrm{e}$ & $08.01 \mathrm{e}$ & $09.71 \mathrm{c}$ \\
\hline SS & $5.49 a b$ & $5.67 \mathrm{~b}$ & 6.17 & 8.79 & $9.52 \mathrm{a}$ & 9.67 & $28.49 \mathrm{ab}$ & $31.89 \mathrm{ab}$ & $35.50 \mathrm{a}$ \\
\hline Comp & $5.48 a b$ & $5.59 \mathrm{bc}$ & 6.09 & 8.77 & $8.36 \mathrm{~b}$ & 9.24 & $19.97 \mathrm{~d}$ & $34.20 \mathrm{a}$ & 34.03 a \\
\hline P-Comp & $5.53 a b$ & $5.60 \mathrm{bc}$ & 5.89 & 8.75 & $8.56 \mathrm{~b}$ & 9.09 & $12.06 \mathrm{e}$ & $16.70 \mathrm{~d}$ & $23.83 \mathrm{~b}$ \\
\hline P-Comp-Soil & $5.60 \mathrm{a}$ & $5.64 b$ & 5.93 & 8.97 & $8.55 b$ & 8.85 & $20.88 c$ & $25.23 \mathrm{c}$ & 23.85 b \\
\hline BPR & $5.43 \mathrm{bc}$ & $5.90 \mathrm{a}$ & 5.67 & 8.75 & $8.32 \mathrm{~b}$ & 9.32 & $26.98 b$ & $30.32 \mathrm{abc}$ & $30.23 a b$ \\
\hline NPK & $5.15 d$ & $5.46 \mathrm{c}$ & 5.79 & 8.73 & $8.35 \mathrm{~b}$ & 9.53 & $32.81 \mathrm{a}$ & $26.27 b c$ & $24.29 \mathrm{~b}$ \\
\hline Sign. Trait & $\star \star$ & * & ns & ns & ** & ns & $\star \star \star$ & $\star \star \star$ & $\star \star \star$ \\
\hline SE & 0.055 & 0.072 & 0.114 & 0.14 & 0.216 & 0.185 & 1.905 & 2.723 & 3.353 \\
\hline Error df & 24 & 24 & 24 & 24 & 24 & 24 & 24 & 24 & 24 \\
\hline
\end{tabular}

Within the same column, values assigned the same letter are not significantly different according to the Student-Newman-Keuls (SNK) test at the

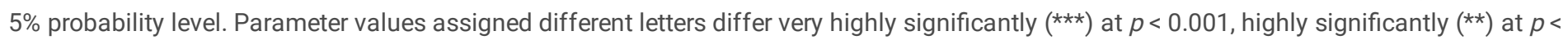
0.01 , and significantly $\left(^{*}\right)$ at $p<0.05, \mathrm{~ns}=$ not significant at $p<0.05$. Control $=$ without phosphate or compost addition, $\mathrm{SS}=$ sorghum straw, Comp = sorghum straw-based compost, P-Comp = sorghum straw-based compost + BPR, P-Comp-soil = compost made from sorghum straw, BPR and sorghum rhizosphere soil, BPR = Burkina phosphate rock, Sign. Trait = significance trait, SE = Standard error, Error df = Error degree of freedom, DMRT = Duncan's multiple range test.

Table 4 One-way ANOVA (treatment) of gcd, AMF, pstS genes over the three sample periods

\begin{tabular}{|c|c|c|c|c|c|c|c|c|c|}
\hline \multirow[t]{2}{*}{ Treatments } & \multicolumn{3}{|l|}{ gcd } & \multicolumn{3}{|l|}{ AMF } & \multicolumn{3}{|l|}{ pstS } \\
\hline & $52^{\text {nd }}$ day & $93^{\text {rd }}$ day & $115^{\text {th }}$ day & $52^{\text {nd }}$ day & $93^{\text {rd }}$ day & $\begin{array}{l}115^{\text {th }} \\
\text { day }\end{array}$ & $52^{\text {nd }}$ day & $93^{\text {rd }}$ day & $\begin{array}{l}115^{\text {th }} \\
\text { day }\end{array}$ \\
\hline Control & $\begin{array}{l}3.20 E+05 \\
b\end{array}$ & $2.50 \mathrm{E}+05$ & $2.94 \mathrm{E}+05$ & $\begin{array}{l}6.75 E+05 \\
d\end{array}$ & $8.12 \mathrm{E}+05$ & $\begin{array}{l}2.42 E+06 \\
\text { cd }\end{array}$ & $\begin{array}{l}3.93 E+05 \\
b\end{array}$ & $7.47 \mathrm{E}+05$ & $\begin{array}{l}5.57 E+05 \\
b\end{array}$ \\
\hline SS & $\begin{array}{l}2.60 \mathrm{E}+05 \\
\mathrm{bc}\end{array}$ & $3.20 \mathrm{E}+05$ & $3.03 \mathrm{E}+05$ & $\begin{array}{l}9.41 \mathrm{E}+05 \\
\mathrm{bcd}\end{array}$ & $9.76 \mathrm{E}+05$ & $\begin{array}{l}7.30 E+06 \\
a\end{array}$ & $\begin{array}{l}4.40 \mathrm{E}+05 \\
\mathrm{~b}\end{array}$ & $4.61 \mathrm{E}+05$ & $\begin{array}{l}6.19 E+05 \\
b\end{array}$ \\
\hline Comp & $\begin{array}{l}2.91 \mathrm{E}+05 \\
\mathrm{bc}\end{array}$ & $3.55 \mathrm{E}+05$ & $2.20 \mathrm{E}+05$ & $\begin{array}{l}9.99 \mathrm{E}+05 \\
\mathrm{abc}\end{array}$ & $1.01 E+05$ & $\begin{array}{l}4.05 E+06 \\
b\end{array}$ & $\begin{array}{l}6.07 E+05 \\
b\end{array}$ & $4.38 \mathrm{E}+05$ & $\begin{array}{l}6.90 E+05 \\
b\end{array}$ \\
\hline P-Comp & $\begin{array}{l}2.64 \mathrm{E}+05 \\
\mathrm{bc}\end{array}$ & $2.38 \mathrm{E}+05$ & $3.19 \mathrm{E}+05$ & $\begin{array}{l}1.27 \mathrm{E}+06 \\
\mathrm{a}\end{array}$ & $8.81 \mathrm{E}+05$ & $\begin{array}{l}3.69 \mathrm{E}+06 \\
\mathrm{bc}\end{array}$ & $\begin{array}{l}5.92 \mathrm{E}+05 \\
\mathrm{~b}\end{array}$ & $3.75 \mathrm{E}+05$ & $\begin{array}{l}1.03 E+06 \\
a\end{array}$ \\
\hline $\begin{array}{l}\text { P-Comp- } \\
\text { Soil }\end{array}$ & $\begin{array}{l}4.74 E+05 \\
a\end{array}$ & $2.87 \mathrm{E}+05$ & $2.59 \mathrm{E}+05$ & $\begin{array}{l}1.13 E+06 \\
a b\end{array}$ & $1.22 \mathrm{E}+06$ & $\begin{array}{l}2.64 \mathrm{E}+06 \\
\text { cd }\end{array}$ & $\begin{array}{l}1.26 \mathrm{E}+06 \\
\mathrm{a}\end{array}$ & 4.93E+05 & $\begin{array}{l}5.90 E+05 \\
b\end{array}$ \\
\hline BPR & $\begin{array}{l}2.92 \mathrm{E}+05 \\
\mathrm{bc}\end{array}$ & $3.29 E+05$ & $2.80 \mathrm{E}+05$ & $\begin{array}{l}9.48 \mathrm{E}+05 \\
\mathrm{bcd}\end{array}$ & $1.23 \mathrm{E}+06$ & $\begin{array}{l}2.31 E+06 \\
d\end{array}$ & $\begin{array}{l}9.86 \mathrm{E}+05 \\
\mathrm{a}\end{array}$ & $5.86 \mathrm{E}+05$ & $\begin{array}{l}5.23 E+05 \\
b\end{array}$ \\
\hline NPK & $\begin{array}{l}2.10 E+05 \\
c\end{array}$ & $2.59 \mathrm{E}+05$ & $2.64 \mathrm{E}+05$ & $\begin{array}{l}7.44 \mathrm{E}+05 \\
\mathrm{~cd}\end{array}$ & $1.38 \mathrm{E}+06$ & $\begin{array}{l}2.58 \mathrm{E}+06 \\
\mathrm{~cd}\end{array}$ & $\begin{array}{l}5.50 \mathrm{E}+05 \\
\mathrm{~b}\end{array}$ & $5.95 \mathrm{E}+05$ & $\begin{array}{l}6.93 E+05 \\
b\end{array}$ \\
\hline Sign. Trait & ** & ns & ns & * & ns & $\star * \star$ & $\star \star \star$ & ns & * \\
\hline SE & $3.79 \mathrm{E}+04$ & $3.82 \mathrm{E}+04$ & $3.11 \mathrm{E}+04$ & $1.29 \mathrm{E}+05$ & $2.21 \mathrm{E}+05$ & $\begin{array}{l}5.88 \mathrm{E} \\
+05\end{array}$ & 1.27E+05 & 7.97E+05 & $1.08 \mathrm{E}+05$ \\
\hline Error df & 24 & 24 & 24 & 24 & 24 & 24 & 24 & 24 & 24 \\
\hline
\end{tabular}

Control $=$ without phosphate or compost addition, $\mathrm{SS}=$ sorghum straw, Comp = sorghum straw-based compost, $\mathrm{P}$-Comp $=$ sorghum straw-based compost + BPR, P-Comp-soil = compost made from sorghum straw, BPR and sorghum rhizosphere soil, BPR = Burkina phosphate rock, Trait Sign. = Significant Trait, parameter values assigned by different letters differ highly significantly (**) at $p<0.01$ and significantly ( $)$ at $p<0.05$, 
ns = significant sound. SE = Standard error, Error df = Error degree of freedom, DMRT = Duncan's multiple range test, LSD $=$ Least small difference, $g c d$ = glucose dehydrogenase, AMF = Arbuscular mycorrhizal fungi, $p s t S=$ phosphate specific transporter.

Table 5 Abundance of some microbial genes in the rhizosphere of sorghum

\begin{tabular}{|c|c|c|c|c|c|c|c|}
\hline \multirow[t]{2}{*}{ Variables } & phnX & phoD & ITS fungi & $16 S r R N A$ & ent $A$ & $p q q E$ & aphA \\
\hline & \multicolumn{7}{|c|}{ Copy number ( $\mathrm{g}^{-1}$ dry soil) } \\
\hline \multicolumn{8}{|c|}{ Treatment effect (comparison based on DMRT) } \\
\hline Control & $3.45 \mathrm{E}+05 \mathrm{~b}$ & $9.56 \mathrm{E}+06$ & 3.37E+07 d & $4.38 \mathrm{E}+08 \mathrm{bc}$ & $3.61 \mathrm{E}+06$ & $3.53 \mathrm{E}+05 \mathrm{~b}$ & 1.69E+05 c \\
\hline SS & $3.60 E+05 b$ & $1.06 \mathrm{E}+07$ & $3.63 \mathrm{E}+07 \mathrm{~cd}$ & $4.61 \mathrm{E}+08 \mathrm{ab}$ & $4.49 \mathrm{E}+06$ & $3.94 \mathrm{E}+05 \mathrm{~b}$ & $2.13 \mathrm{E}+05 \mathrm{bc}$ \\
\hline Comp & $4.42 \mathrm{E}+05 \mathrm{a}$ & $1.04 \mathrm{E}+07$ & $4.23 E+07 b$ & $4.56 \mathrm{E}+08 \mathrm{ab}$ & $3.60 \mathrm{E}+06$ & 8.19E+05 a & 1.37E+07 c \\
\hline P-Comp & $4.12 \mathrm{E}+05 \mathrm{a}$ & $9.06 \mathrm{E}+06$ & $3.60 \mathrm{E}+07 \mathrm{~cd}$ & $4.89 \mathrm{E}+08 \mathrm{ab}$ & $3.64 \mathrm{E}+06$ & $2.88 \mathrm{E}+05 \mathrm{bc}$ & $2.91 \mathrm{E}+05 \mathrm{~b}$ \\
\hline P-Comp-Soil & $4.22 \mathrm{E}+05 \mathrm{a}$ & $1.09 \mathrm{E}+07$ & $4.08 E+07 b$ & $5.17 E+08 a$ & $3.96 E+06$ & $7.93 E+05 a$ & $4.98 \mathrm{E}+05 \mathrm{a}$ \\
\hline BPR & $3.59 E+05 b$ & $8.52 \mathrm{E}+06$ & $3.95 E+07 b c$ & $3.88 \mathrm{E}+08 \mathrm{c}$ & $4.04 \mathrm{E}+06$ & $2.03 E+05 c$ & $1.91 \mathrm{E}+05 \mathrm{c}$ \\
\hline NPK & $2.93 E+05 c$ & $1.01 \mathrm{E}+07$ & $4.85 E+07 a$ & $4.39 E+08 b c$ & $3.42 \mathrm{E}+06$ & $8.43 \mathrm{E}+05 \mathrm{a}$ & $1.53 E+05 c$ \\
\hline Sign. Trait & * & ns & * & * & ns & ** & * \\
\hline SE & $2.13 E+04$ & $8.02 E+05$ & $1.78 \mathrm{E}+06$ & $2.68 \mathrm{E}+07$ & $4.63 E+05$ & $5.07 E+04$ & $3.75 \mathrm{E}+04$ \\
\hline Error df & 52 & 56 & 51 & 49 & 50 & 43 & 29 \\
\hline \multicolumn{8}{|c|}{ Effect of sampling period (comparison based on LSD) } \\
\hline $52^{\text {nd }}$ day & $2.88 \mathrm{E}+05 \mathrm{~b}$ & $1.22 \mathrm{E}+07 \mathrm{a}$ & $3.30 \mathrm{E}+07$ & $4.35 \mathrm{E}+08$ & $3.95 \mathrm{E}+06 \mathrm{a}$ & $1.13 E+06 a$ & $3.11 \mathrm{E}+05$ \\
\hline $93^{\text {rd }}$ day & $3.23 E+05 b$ & $9.44 \mathrm{E}+06 \mathrm{~b}$ & $4.10 \mathrm{E}+07$ & $4.36 \mathrm{E}+08$ & $2.82 \mathrm{E}+06 \mathrm{~b}$ & $2.71 E+05 b$ & $2.55 \mathrm{E}+05$ \\
\hline $115^{\text {th }}$ day & $5.18 \mathrm{E}+05 \mathrm{a}$ & $8.05 E+06 b$ & $4.48 \mathrm{E}+07$ & $4.95 \mathrm{E}+08$ & $4.70 \mathrm{E}+07 \mathrm{a}$ & $1.84 \mathrm{E}+05 \mathrm{~b}$ & $1.42 \mathrm{E}+05$ \\
\hline Sign. Trait & ** & $\star \star$ & ns & ns & ** & * & ns \\
\hline $\operatorname{LSD}_{0.05}(\mathrm{n}=35)$ & 1.17E+05 & $1.96 \mathrm{E}+06$ & $1.12 \mathrm{E}+07$ & $9.30 \mathrm{E}+07$ & $8.26 E+05$ & $6.31 \mathrm{E}+05$ & $2.86 \mathrm{E}+05$ \\
\hline
\end{tabular}

Control $=$ without phosphate or compost addition, $\mathrm{SS}=$ sorghum straw, Comp = sorghum straw-based compost, $\mathrm{P}$-Comp $=$ sorghum straw-based compost + BPR, P-Comp-soil = compost made from sorghum straw, BPR and sorghum rhizosphere soil, BPR = Burkina phosphate rock, Trait Sign. = Significant Trait, parameter values assigned by different letters differ highly significantly (**) at $p<0.01$ and significantly $(*)$ at $p<0.05$, $\mathrm{ns}=$ significant sound. SE = Standard error, Error df = Error degree of freedom, DMRT = Duncan's multiple range test, LSD = Least significant difference, $p h n X=$ phosphonatase, $p h o D=$ alkaline phosphatase, $I T S=$ Internal transcribed spacer (total fungi), $16 S r R N A$ (total bacteria), ent $A=$ enterobactin-mediated Siderophore, $p q q E=$ pyrroloquinoline quinone, $a p h A=$ acid phosphatase.

\section{Figures}



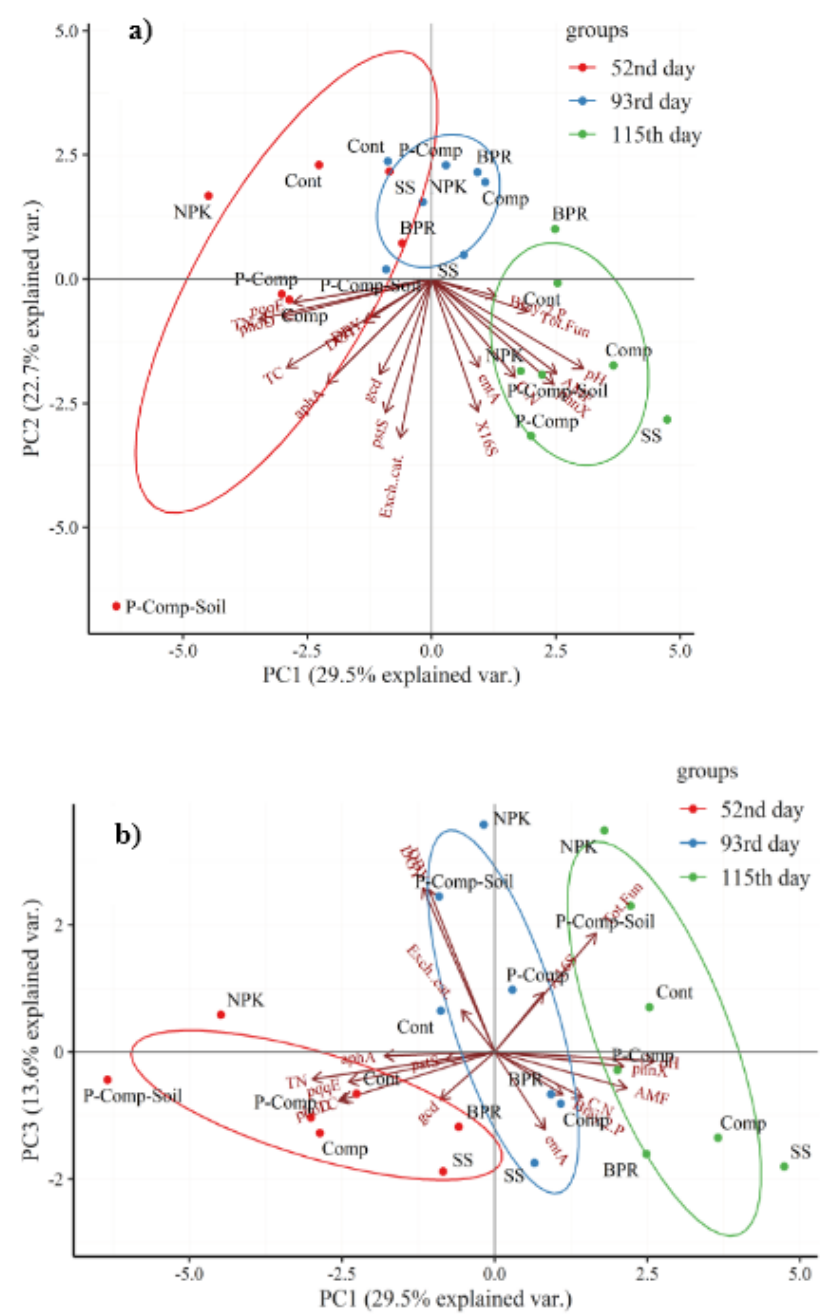

Figure 1

Principal Component Analysis of sorghum yield components and soil and characteristics

$\mathrm{TN}=$ Total Nitrogen; $\mathrm{TC}=$ Total Carbon, Exch..cat $=$ Sum of exchangeable cations, Bray.2.P = available phosphorus by Bray -2 method, $p h n X=$ phosphonatase gene, $p h o D=$ alkaline phosphatase gene, Tot-Fun = Total Fungi (ITS), X16S = Total Bacteria (16S rRNA), gcd = glucose dehydrogenease gene, ent $A$ = enterobactin gene (siderophore), AMF = Arbuscular Mycorrhizal Fungi, $p s t S=$ phosphate specific transporter gene, $q p p E=$ Pyrroloquinoline quinone $\mathrm{E}, \mathrm{aph} A=$ acid phosphatase gene, $\mathrm{DBY}=$ dry Biomass yield, $\mathrm{DGY}=$ dry grain yield, Cont. $=$ control without phosphate or compost addition, SS = sorghum straw, Comp = sorghum straw-based compost, P-Comp = sorghum straw-based compost + BPR, P-Comp-soil = compost made from sorghum straw, BPR and sorghum rhizosphere soil, BPR = Burkina phosphate rock. Vectors exert more influence on a PC if the locate further away from that PC origin. A narrow angle implies a positive correlation between two variables, while a large one suggests a negative correlation. A $90^{\circ}$ angle indicates no correlation between two characteristics.

\section{Supplementary Files}

This is a list of supplementary files associated with this preprint. Click to download.

- SupplementaryTables.docx 